\title{
Photodynamic Therapy for Oral Herpes Simplex Infections: It can be Possible?
}

\author{
Matteo Fanuli ${ }^{1}$, Cinzia Casu ${ }^{2 *}$ and Luca Viganò ${ }^{3}$ \\ ${ }^{1}$ Department of Biomedical, Surgical and Dental Sciences, University of Milan, Italy \\ ${ }^{2}$ Private Dental Practice, Italy \\ ${ }^{3}$ Department of Radiology, University of Milan, Italy
}

Submission: May 09, 2018; Published: May 15, 2018

*Corresponding author: Cinzia Casu, Private Dental Practice, Cagliari, Italy, Email: ginzia.85@hotmail.it

\section{Opinion}

Herpes simplex virus type 1 (HSV-1) is a member of the Alphaherpesviridae subfamily and its structure is composed of linear dsDNA, an icosahedral capsid with a spikey envelope. HSV-1 infection is characterized by a cycle of primary infection of epithelial cells, on the latency primarily in neurons, and reactivation. HSV-1 involved overall oral mucosa [1]. An HSV infections treatment includes topical acyclovir 5\%, pencyclovir $1 \%$, dosoconal $10 \%$, lidocaine, sunscreen sticks for herpes labialis [2].

Photodynamic Therapy (PDT) relies on the interaction between a photosensitizer, a light with the appropriate wavelength, and the presence of oxygen. The reaction between the 3 elements generates ROS in cells that take up the photosensitizer, causing cell death by necrosis or apoptosis, but spares the surrounding tissue [3]. PDT was used in literature for the treatment of oral disease, such as oral lichen planus [4], oral pre-cancerous lesions [5] and oral infections.

Some articles on the treatment of HSV infections are present in scientific literature. In vitro studies made by Zverev et al. [6] shown high sensibility of HSV-1 and Type 2 spp to LLLT mediated by Fotoditazine cromophore leading to a reliable decrease of viral agents content [6].

Marotti et al. [7] presented case series and demonstrated the effectiveness of PDT on recurrent herpes simplex infections on the lips $[7,8]$. All patients treated, were in the vesicular stage, so it was possible to perform PDT treatment on the lesions. The vesicles were carefully perforated with a needle. A methylene blue solution was placed over the lesions, and after $5 \mathrm{~min}$, the excess dye was removed. The lesions were irradiated with a diode laser of $660-\mathrm{nm}$ of wave length [7]. The patients had no recurrences at 6 and 10 months follow-up. Marotti et al. [7] demonstrated also that PDT is effective as the High level laser therapy for HSV infections [8]. Ramalho et al. [9] also proposed the use of Methylen blue as a photosensitizer. Methylene Blue solution was applied topically by authors in a $0.005 \%$ concentration. Five minutes was considered as pre-irradiation time and one point of irradiation was performed over the lesion using a $660 \mathrm{~nm}$ wavelength laser. Irradiation time was 2 min for point [9]. Kvacheva et al. [10] wrote an in vitro study on the effectiveness of PDT associated with 5-aminolevulinic acid [10]. Photo inactivation of herpes simplex virus was evaluated in the past, by rose bengal and fluorescein as photosensitizer [11]. Reactivation of HSV and lesions progressions was a strongly debated topic in PDT mediated herpes lesions therapy [12].

Sperandio et al. [13] established a low risk of recurrent HS lesions and vescicules after PDT followed by a constant and repeated low level laser therapy [13].

Kharkwal et al. [14] further studied the effect on phenothiazinium mediated photo-biostimulation on oral tissues in a review and later discovered low risk of lesion's reactivations when a cromophore medium is applied during the photobiostimulation process [14].

Marotti et al. [15] in a 2010 paper later discovered that intensity, applications, and irradiation power does not alternate the final results and healing process. Patients were treated with High Intensity Laser Therapy (HILT) followed by LLLT or Methylene Blue cromophore medium applied before LLLT stabilizing therapy. Stimulation therapy was applied at $24,48,72 \mathrm{~h}$ and 7 th day. During the six month follow-up period, no patients showed signs or symptoms of recurrent herpes lesions (RHL) $[15,16]$. The evaluation of new cromophore substances represents a principal issue and a largely debated discussion topic in literature.

In 2017 Remichkova et al. [17] evaluated the effect of ZyncPhthalocyanine complexes in genetic alterations of coxsackie spp. First positive result were raised after bovine applications and a HS evaluation should be considered $[17,18]$.

Latief et al. [19] demonstrated that PDT with a porphyrin derived cromophore medium is effective for eliminating HSV-1 
and ACV-resistant HSV-1 without a harmful effect on host cells even in acyclovir resistant agents [19].

Even if the light mediated therapeutic effects in dermatological herpes lesions are increasingly demonstrated, only few papers in scientific literature actually debate on oral HRL applications. Furthermore in vitro and in vivo studies have shown a reliable and significant efficacy of PDT in RHL treatment. Pathogenic mechanisms are far to be widely known and further RCTs and comprehensive reviews need to be performed.

\section{References}

1. Dahlia Saleh, Rene Bermudez (2018) Herpes, simplex, HSV-1. StatPearls [Internet]. Treasure Island (FL): StatPearls Publishing, London.

2. Stoopler ET, Balasubramanlam R (2013) Topical and Systemic Therapies for Oral and Perioral Herpes Simplex Virus Infections. California Dental Association Journal 41(4): 259-262.

3. Barbosa FI, PV Araújo, LJC Machado, CS Magalhães, MMM Guimarães, et al. (2018) Effect of photodynamic therapy as an adjuvant to nonsurgical periodontal therapy: periodontal and metabolic evaluation in patients with type 2 diabetes mellitus. Photodiagnosis Photodyn Ther.

4. Gondivkar SM, AR Gadbail, MG Choudhary, PR Vedpathak, MS Likhitkar (2018) Photodynamic treatment outcomes of potentially-malignant lesions and malignancies of the head and neck region: A systematic review. J Investig Clin Dent 9(1).

5. Mirza S, N Rehman, A Alrahlah, WR Alamri, F Vohra (2018) Efficacy of photodynamic therapy or low level laser therapy against steroid therapy in the treatment of erosiveatrophic oral lichen planus. Photodiagnosis Photodyn Ther 21: 404-408.

6. VV Zverev, OV Makarov, AZ Khashukoeva, OA Svitich, YE Dobrokhotova, et al. (2016) In vitro studies of the antiherpetic effect of photodynamic therapy Lasers Med Sci 31(5): 849-855.

7. Juliana Marotti, Ana Cecília Correa Aranha, Carlos De Paula Eduardo, Martha Simões Ribeiro (2009) Photodynamic Therapy Can Be Effective as a Treatment for Herpes Simplex Labialis. Photomed Laser Surg 27(2): 357-363.

8. Juliana Marotti, Felipe Fornias Sperandio, Eduardo Rodrigues Fregnani, Ana Cecilia Corre^a Aranha, Patrıcia Moreira de Freitas, Carlos de Paula Eduar, et al. (2010) High-Intensity Laser and Photodynamic Therapy as a Treatment for Recurrent Herpes Labialis. Photomed Laser Surg 28(3): 439-444
9. Karen Müller Ramalho, Rodney Garcia Rocha, Ana Cecília CorreaAranha, Sandra Ribeiro de Barros Cunha, Alyne Simões, Luana Campos, et al. (2015) Treatment of herpes simplex labialis inmacule and vesicle phases withphotodynamic therapy. Report of two cases. Photodiagnosis Photodyn Ther 12(2): 321-323.

10. Kvacheva ZB, Lobanok ES, Votiakov VI, Shukanova NA, Vorobeĭ AV, et al. (2005) Photodynamic inhibition of infection caused by herpes simplex virus type 1 in the cultured cells, by using 5 -aminolevulinic acid-induced porphyrins. Vopr Virusol 50(4): 44-47.

11. Brooks SE, Kaza V, Nakamura T, Trousdale MD (1994) Photoinactivation of herpes simplex virus by rose bengal and fluorescein. In vitro and in vivo studies. Cornea 13(1): 43-50.

12. Remichkova M, L Mukova, L Nikolaeva Glomb, N Nikolova, L Doumanova, et al. (2017) Virus inactivation under the photodynamic effect of phthalocyanine zinc (II) complexes. Z Naturforsch C 72(3-4): 123-128.

13. Sperandio FF, J Marotti, AC Aranha, CeP Eduardo (2009) Photodynamic therapy for the treatment of recurrent herpes labialis: preliminary results. Gen Dent 57(4): 415-419.

14. Kharkwal GB, SK Sharma, YY Huang, T Dai, MR Hamblin (2011) Photodynamic therapy for infections: clinical applications. Lasers Surg Med 43(7): 755-767.

15. Marotti J, AC Aranha, CeP Eduardo, MS Ribeiro (2009) Photodynamic therapy can be effective as a treatment for herpes simplex labialis. Photomed Laser Surg 27(2): 357-363.

16. Marotti J, FF Sperandio, ER Fregnani, AC Aranha, PM de Freitas (2010) High-intensity laser and photodynamic therapy as a treatment for recurrent herpes labialis. Photomed Laser Surg 28(3): 439-444.

17. Remichkova M, L Mukova, L Nikolaeva Glomb, N Nikolova, L Doumanova, et al. (2017) Virus inactivation under the photodynamic effect of phthalocyanine zinc (II) complexes. Z Naturforsch C 72(3-4): 123-128.

18. Ke MR, JM Eastel, KL Ngai, YY Cheung, PK Chan, et al. (2014) Photodynamic inactivation of bacteria and viruses using two monosubstituted zinc(II) phthalocyanines. Eur J Med Chem 84: 278283.

19. Latief MA, T Chikama, JA Ko, Y Kiuchi, T Sakaguchi et al. (2015) Inactivation of acyclovir-sensitive and -resistant strains of herpes simplex virus type 1 in vitro by photodynamic antimicrobial chemotherapy.

\section{Your next submission with Juniper Publishers will reach you the below assets}

- Quality Editorial service

- Swift Peer Review

- Reprints availability

- E-prints Service

- Manuscript Podcast for convenient understanding

- Global attainment for your research

- Manuscript accessibility in different formats

( Pdf, E-pub, Full Text, Audio)

- Unceasing customer service

Track the below URL for one-step submission https://juniperpublishers.com/online-submission.php 